\title{
Non-chemical methods to break seed dormancy of canafistula [Peltophorum dubium (Sprengel) Taubert (Fabaceae)]
}

\author{
Alan Mario Zuffo ${ }^{1}$, Fábio Steiner ${ }^{1}$, Joacir Mario Zuffo Júnior ${ }^{2}$, Aécio Bush ${ }^{1}$, Jefferson Rogério \\ Marques da Silva ${ }^{1}$, Arnaldo Cintra Limede ${ }^{1}$, Carlos Eduardo da Silva Oliveira ${ }^{1}$ \\ ${ }^{1}$ Department of Crop Production, State University of Mato Grosso do Sul, 79540-000, Cassilândia, Mato Grosso \\ do Sul, Brazil \\ ${ }^{2}$ Department of Agronomy, State University Mato Grosso, 786900-000, Nova Xavantina, Mato Grosso, Brazil
}

*Corresponding author: alan_zuffo@ hotmail.com

\begin{abstract}
Canafistula seeds have a naturally slow and irregular germination due to tegument impermeability. In this study, the efficacy of nonchemical methods was investigated to break the tegument dormancy and enhance the germination rate of canafistula [Peltophorum dubium (Spreng.) Taub. - (Fabaceae)] seeds. A completely randomized design with eight treatments of seed dormancy breaking and four replications of 25 seeds each was used. Different methods to break the seed dormancy were compared: T1: untreated seeds to break dormancy (control); T2: sanding; T3: soaked in hot water $\left(95^{\circ} \mathrm{C}\right)$ and cooled for 24 hours; T4: pre-soaking in boiling water $\left(100{ }^{\circ} \mathrm{C}\right)$ for 5 minutes; T5, T6 T7 and T8: seeds exposed to dry heating in an oven at $40{ }^{\circ} \mathrm{C}$ for $24,48,72$ and 96 hours, respectively. All seeds were germinated in sand, and kept in a greenhouse conditions for 25 days. The emergence capacity, emergence rate index, plant growth rate, dry matter partitioning into roots and shoots, and vigor index of canafistula seedlings were measured. Mechanical scarification (sanding) and soaking in hot water $\left(95^{\circ} \mathrm{C}\right)$ and cooled for 24 hours were efficient to breaking the tegument dormancy and enhanced the seed emergence rate and vigor of Peltophorum dubium (Fabaceae) seedlings.
\end{abstract}

Keywords: Tegument impermeability, emergence rate, seedling vigor, forest species.

Abbreviations: EC_emergence capacity; ERI_emergence rate index; MET_mean emergence time; SL_shoot length; RL_radicle length; CD_root collar diameter; SDM_shoot dry matter; RDM_root dry matter; RSR_root: shoot ratio; SQ_sturdiness quotient; SVI_seedling vigor index.

\section{Introduction}

Peltophorum dubium (Spreng.) Taub., Fabaceae Caesalpinioideae, commonly known in Brazil as "canafistula" or "angico amarelo", is a tree native to South America and widely used in reforestation of degraded areas and mixed plantations, mainly for its fast initial growth and rusticity (Lorenzi, 2002). Seeds have a high degree of dormancy mainly caused by seed coat's impermeability to water (Carvalho, 2003). Impermeable seed coats to water or oxygen, mechanical restrictions or combinations of these factors, together with presence of chemical inhibitors are often found in tropical tree seeds (Malavasi, 1988). Although it is an efficient mechanism to guarantee the survival and perpetuation of the species, seed dormancy is the major critical factor for propagation and expansion of large-scale cultivation of $P$. dubium in nurseries. Tropical tree seeds with hard seed coats have delayed and non-uniformed germination, causing loss of over two-thirds of the genetic resources if a non-effective dormancy suppression treatment is employed. Malavasi and Malavasi (2004) reported that only $2 \%$ of timburi [Enterolobium contortisiliquum (Vell.) Morong. (Mimosaceae)] seeds not subjected to dormancy breaking treatment germinated, while the mechanical scarification (sanding) increased the germination to $92 \%$.

In order to define methods to break the tegument dormancy in $P$. dubium seeds several studies were carried out to evaluate the mechanical and chemical scarification, and soaking the seeds in hot water. However, the results of these studies are contradictory and there is still no a universal technique for improving seed germination rate. Mechanical and chemical scarification was effective in breaking seed dormancy in canafistula as reported by Bianchetti and Ramos (1982) and Guerra et al. (1982). On the other hand, the presoaking of canafistula seeds in boiling water $\left(100{ }^{\circ} \mathrm{C}\right)$ was more effective in promoting germination rate (Salerno et al. 1996). Bianchetti and Ramos (1982) found that immersion of seeds in hot water at temperatures of $95^{\circ} \mathrm{C}, 90^{\circ} \mathrm{C}, 80^{\circ}$ and $70{ }^{\circ} \mathrm{C}$, followed by soaking in water at room temperature for 24 hours were not effective in breaking seed dormancy. These findings differ from the results reported by Oliveira et al. (2003), who showed that immersion of canafistula seeds in hot water $\left(95^{\circ} \mathrm{C}\right)$ and cooled for 24 hours, was efficient for promoting seed germination, and is practical.

The method of breaking seed dormancy by chemical scarification consists in using concentrated sulfuric acid for different times, under laboratory conditions (Kobori et al., 2013). However, the use of concentrated sulfuric acid $\left(\mathrm{H}_{2} \mathrm{SO}_{4}\right)$ may have inherent burn risk to the operator or someone close, have the necessity of an appropriate location for your disposal, as well as the difficulty to use it on a large scale due to the care necessary for their application and cost, especially when compared to methods that use water (Oliveira et al., 2003). 
Due to the contradictory results reported in the literature for methods of overcoming seed dormancy in canafistula, associated the difficulties of using sulfuric acid in the chemical scarification. The objective of this investigation was to identify the best pre-sowing non-chemical treatment to break seed dormancy and to enhance the germination rate of canafistula [Peltophorum dubium (Spreng.) Taub.] seeds.

\section{Results and discussion}

\section{Emergence and seedling growth}

A summary of the analysis of variance for the measurements of emergence, initial growth and quality indexes of seedlings is shown in Table 1. The results of the analysis of variance showed significant effects $(P<0.01)$ for the effects of dormancy breaking treatments in many of the measured traits, except root length, root dry matter, and root: shoot dry matter ratio (Table 1).

The application of different methods to break dormancy did not affect the majority of traits related to growth of the roots (Table 2). The values of the radicle length, root dry matter and root: shoot ratio were $7.70 \pm 1.02 \mathrm{~cm}, 14.24 \pm 3.92 \mathrm{mg}$ seedling ${ }^{-1}$ and $0.32 \pm 0.06 \mathrm{~g} \mathrm{~g}^{-1}$, respectively.

In general, the results presented here indicate that mechanical scarification - sanding (T2) and soaking in hot water $\left(95{ }^{\circ} \mathrm{C}\right)$, followed by soaking in water at room temperature for 24 hours (T3) were the most efficient methods to breaking the tegument dormancy. The application of these methods promoted the highest values of emergence (Figure 3A), emergence rate index (Figure 3B), shoot dry matter (Figure 3F), seedling vigor index (Figure 3H) and lower mean emergence time of $P$. dubium seedlings (Figure 3C). These results are similar to those reported by Oliveira et al. (2003), who found that immersion of P. dubium seeds in hot water $\left(95^{\circ} \mathrm{C}\right)$ a and cooled for 24 hours, away from heat, was efficient for promoting seed germination. On the other hand, Lazzarotto et al. (2013) showed that imbibition of seeds for 10 minutes in hot water $\left(80{ }^{\circ} \mathrm{C}\right)$ resulted in higher germination percentage of the $P$. dubium seeds.

The cause of $P$. dubium seed dormancy is due to a waterimpermeable seed coat (physical dormancy, as reported by Bertolini et al. (2015). Thus, the structure and/or chemical composition of the seed coat prevents the seed's water uptake, making germination not possible (Marcos-Filho, 2005). Therefore, methods of mechanical scarification (sanding) and soaking in hot water $\left(95{ }^{\circ} \mathrm{C}\right)$, followed by soaking in water at room temperature for 24 hours had higher efficacy due to improvement of seed imbibition, which is the first step to occur germination process. This is because, when sanding the seed results in the seed coat rupture, and presoaking in hot water at $95{ }^{\circ} \mathrm{C}$ results in the seed coat softening favoring the seed water uptake.

On the other hand, pre-soaking in boiling water $\left(100{ }^{\circ} \mathrm{C}\right)$ for 5 minutes and exposure of the seeds in dry heating (40 ${ }^{\circ} \mathrm{C}$ ) for $24,48,72$ and 96 hours did not result in alterations in the seed coat permeability, in order to improve the germination process as observed the emergence percentage (Figure 3A). Thus, the use of these heating methods was not effective in breaking dormancy of $P$. dubium seeds.

The shoot length of seedlings were not significantly affected for the majority of dormancy breaking methods used, except for the untreated seeds (T1) and the exposure to dry heating $\left(40{ }^{\circ} \mathrm{C}\right.$ ) for 72 hours (T7) (Figure 3D). These results are different from those reported Lazzarotto et al. (2013), who found that the soaking of the seeds in hot water $\left(80^{\circ} \mathrm{C}\right)$ for
10 minutes promoted higher shoot length of $P$. dubium seedlings.

The larger root collar diameter was observed for the seedlings from treatments of mechanical scarification (T2), soaking in hot water $\left(95^{\circ} \mathrm{C}\right)$, and cooled for 24 hours (T3) and untreated seeds (T1) (Figure 3E). The lowest values of sturdiness quotient were observed in treatment with mechanical scarification (T2) and untreated seeds (T1) (Figure 3G). The 'sturdiness quotient' is a seedling quality index that compares height (in $\mathrm{cm}$ ) over root collar diameter (in mm) (Duryea, 1985). A small quotient indicates a sturdy plant with a higher expected chance of survival, especially on windy or dry sites. A sturdiness quotient higher than 6.0 is undesirable (Duryea, 1985). Based on this inference only treatments with exposure of the seeds in dry heating $\left(40^{\circ} \mathrm{C}\right)$ for 48 (T6) and 96 hours (T8) showed a sturdiness quotient undesirable. In turn, despite the seedlings from the treatment without breaking dormancy (T1) have one of the best quality scores, it should be noted that in this treatment there was a low emergence percentage, as reported in Figure 3A.

The treatment with mechanical scarification - sanding (T2) and soaking in hot water $\left(95{ }^{\circ} \mathrm{C}\right)$, followed by soaking in water at room temperature for 24 hours (T3) resulted in $P$. dubium seedlings with the highest quality indexes (Figure $3 \mathrm{H})$. Therefore, these methods should be considered the best treatments to overcome seed dormancy of $P$. dubium, because its practical aspects are important for the seedling production in forest nurseries. This agrees with results from several authors. Bianchetti and Ramos (1982) and Guerra et al. (1982) reported that the mechanical scarification turned out to be an excellent treatment to breaking seed dormancy in $P$. dubium. Oliveira et al. (2003) showed that soaking of $P$. dubium seeds in hot water $\left(95^{\circ} \mathrm{C}\right)$ and cooled for 24 hours was efficient to break seed dormancy. However, Bianchetti and Ramos (1982) found that soaking of $P$. dubium seeds in hot water at temperatures of $95^{\circ} \mathrm{C}, 90{ }^{\circ} \mathrm{C}, 80^{\circ}$ and $70{ }^{\circ} \mathrm{C}$, followed by soaking in water at room temperature for 24 hours were not effective in breaking seed dormancy.

\section{Correlation analysis}

The results of simple linear correlation analysis between the characteristics measured of the $P$. dubium seedlings indicate that there was a high degree of positive association and significance between seedling emergence with the emergence rate index (ERI), shoot length (SL), root length (RL); root collar diameter (CD), shoot dry matter (SDM) and seedling vigor index (SVI), and the linear correlation coefficients (Pearson's r) ranged from 0.4300 to 0.9776 (Table 2). The emergence rate index correlated significantly with the shoot (SL) and root length (RL), root collar diameter (CD), shoot dry matter (SDM) and vigor index (SVI), and the correlation coefficients ranged from 0.4048 to 0.9944 (Table 2). The shoot length correlated significantly with the shoot (SDM) and root dry matter (RDM), sturdiness quotient (SQ) and vigor index (SVI), and the correlation coefficients ranged from 0.3590 to 0.6562 (Table 2). The root length correlated significantly with the root collar diameter (CD), shoot (SDM) and root dry matter (RDM) and vigor index (SVI), and correlation coefficients ranged from 0.3856 to 0.6791 (Table 2 ). The root collar diameter correlated significantly with the shoot dry matter $(\mathrm{r}=0.5644 ; P=0.05)$, sturdiness quotient $(\mathrm{r}$ $=-0.7676 ; P=0.01)$ and vigor index $(\mathrm{r}=0.5185 ; P=0.01)$ (Table 2). The shoot dry matter correlated significantly with the root dry matter $(\mathrm{r}=0.6752 ; P=0.01)$ and vigor index $(\mathrm{r}=$ $0.6924 ; P=0.01$ ), while the correlation coefficients between 
Table 1. Summary of the analysis of variance for the emergence capacity (EC), emergence rate index (ERI), mean emergence time (MET), shoot length (SL), radicle length (RL), root collar diameter (CD), shoot dry matter (SDM), root dry matter (RDM), root: shoot ratio (RSR), sturdiness quotient (SQ) and seedling vigor index (SVI) for the effects of dormancy breaking treatments. Cassilândia, MS, Brazil, 2016.

\begin{tabular}{|c|c|c|c|c|c|c|c|c|c|c|c|}
\hline \multicolumn{12}{|c|}{ Causes of Probability $>F$} \\
\hline variation & $\mathrm{EC}$ & ERI & MET & SL & RL & DC & SDM & RDM & RSR & SQ & SVI \\
\hline Treatments & $<0.000$ & $<0.000$ & $<0.000$ & $<0.000$ & 0.105 & $<0.000$ & $<0.000$ & 0.2662 & 0.166 & $<0.000$ & $<0.000$ \\
\hline $\mathrm{CV}(\%)$ & 6.90 & 5.43 & 12.96 & 7.27 & 11.83 & 6.48 & 14.66 & 11.11 & 8.36 & 10.56 & 19.56 \\
\hline
\end{tabular}

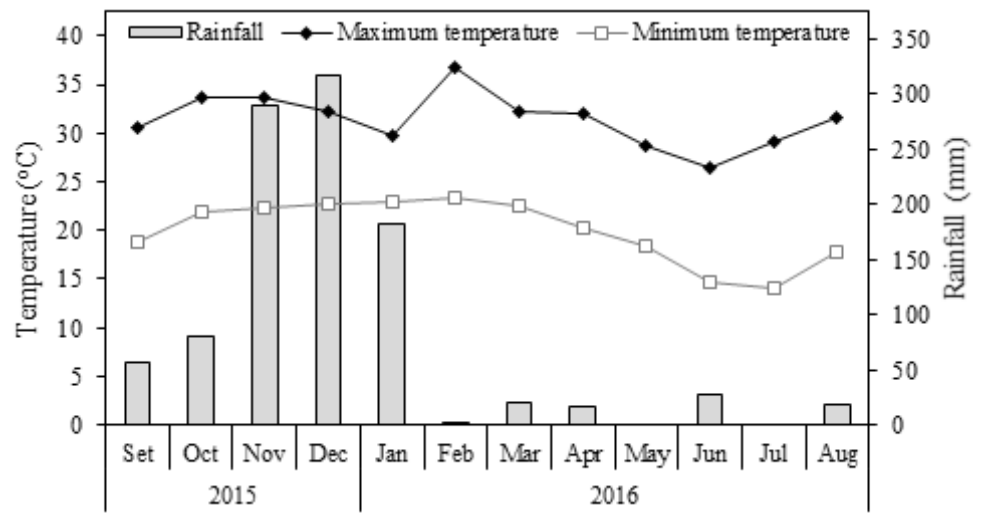

Fig 1. Minimum and maximum temperature $\left({ }^{\circ} \mathrm{C}\right)$ and total monthly rainfall $(\mathrm{mm})$ occurred during the flowering period and fruit formation of Peltophorum dubium in the years 2015 and 2016. Fonte: Meteorological station of the National Institute of Meteorology - INMET in Cassilândia, MS, Brazil.

Table 2. Simple linear correlation coefficient (Pearson's r) between the different traits measured in the study of seed dormancy breaking of canafístula [Peltophorum dubium (Sprengel) Taubert]. Cassilândia, MS, Brazil, 2016.

\begin{tabular}{|c|c|c|c|c|c|c|c|c|c|c|c|}
\hline & $\mathrm{EC}$ & MET & ERI & SL & RL & $\mathrm{CD}$ & SDM & RDM & RSR & SQ & SVI \\
\hline$\overline{\mathrm{EC}}$ & 1 & & & & & & & & & & \\
\hline MET & $-0.7816 * *$ & & & & & & & & & & \\
\hline ERI & $0.9776^{* *}$ & $-0.8564 * *$ & & & & & & & & & \\
\hline SL & $0.4878 * *$ & $-0.4579 * *$ & $0.4883 * *$ & & & & & & & & \\
\hline RL & $0.4300 * *$ & $-0.2146^{\mathrm{ns}}$ & $0.4048 *$ & $0.1246^{\mathrm{NS}}$ & 1 & & & & & & \\
\hline $\mathrm{CD}$ & $0.5278 * *$ & $-0.4322 * *$ & $0.5379 * *$ & $0.0204^{\mathrm{NS}}$ & $0.6018 * *$ & & & & & & \\
\hline SDM & $0.6653 * *$ & $-0.5059 * *$ & $0.6626^{* *}$ & $0.6562 * *$ & $0.6791 * *$ & $0.5644 *$ & 1 & & & & \\
\hline RDM & $0.2117^{\mathrm{NS}}$ & $-0.0805^{\mathrm{NS}}$ & $0.1771^{\mathrm{NS}}$ & $0.3590 *$ & $0.5398 * *$ & $0.3326^{\mathrm{NS}}$ & $0.6752 * *$ & 1 & & & \\
\hline RSR & $-0.2620^{\mathrm{NS}}$ & $0.2890^{\mathrm{NS}}$ & $-0.3080^{\mathrm{NS}}$ & $-0.0691^{\mathrm{NS}}$ & $0.1565^{\mathrm{ns}}$ & $0.0122^{\mathrm{NS}}$ & $0.0793^{\mathrm{NS}}$ & $0.7782 * *$ & 1 & & \\
\hline SQ & $-0.1262^{\mathrm{NS}}$ & $0.1017^{\mathrm{NS}}$ & $-0.1401^{\mathrm{NS}}$ & $0.6086^{* *}$ & $-0.3354^{\mathrm{ns}}$ & $-0.7676^{* *}$ & $-0.0115^{\mathrm{NS}}$ & $0.0007^{\mathrm{NS}}$ & $-0.0242^{\mathrm{NS}}$ & 1 & \\
\hline SVI & $0.9742 * *$ & $-0.8415 * *$ & $0.9944 * *$ & $0.5548 * *$ & $0.3856^{*}$ & $0.5185 * *$ & $0.6924 * *$ & $0.2029^{\mathrm{NS}}$ & $-0.2973^{\mathrm{NS}}$ & -0 . & \\
\hline
\end{tabular}

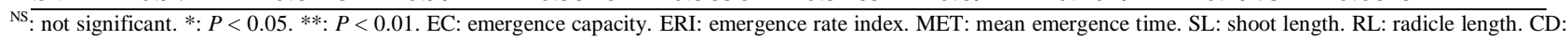
root collar diameter. SDM: shoot dry matter. RDM: root dry matter. RSR: root: shoot ratio. SQ: sturdiness quotient. SVI: seedling vigor index.

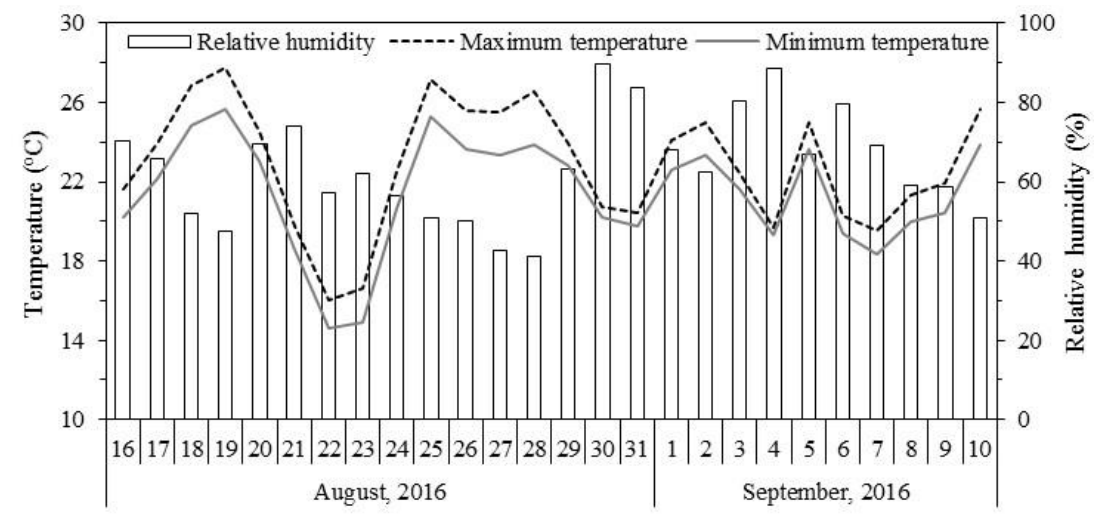

Fig 2. Minimum and maximum temperature $\left({ }^{\circ} \mathrm{C}\right)$ and mean relative humidity $(\%)$ inside the greenhouse during the period of plant emergence and establishment of Peltophorum dubium. 

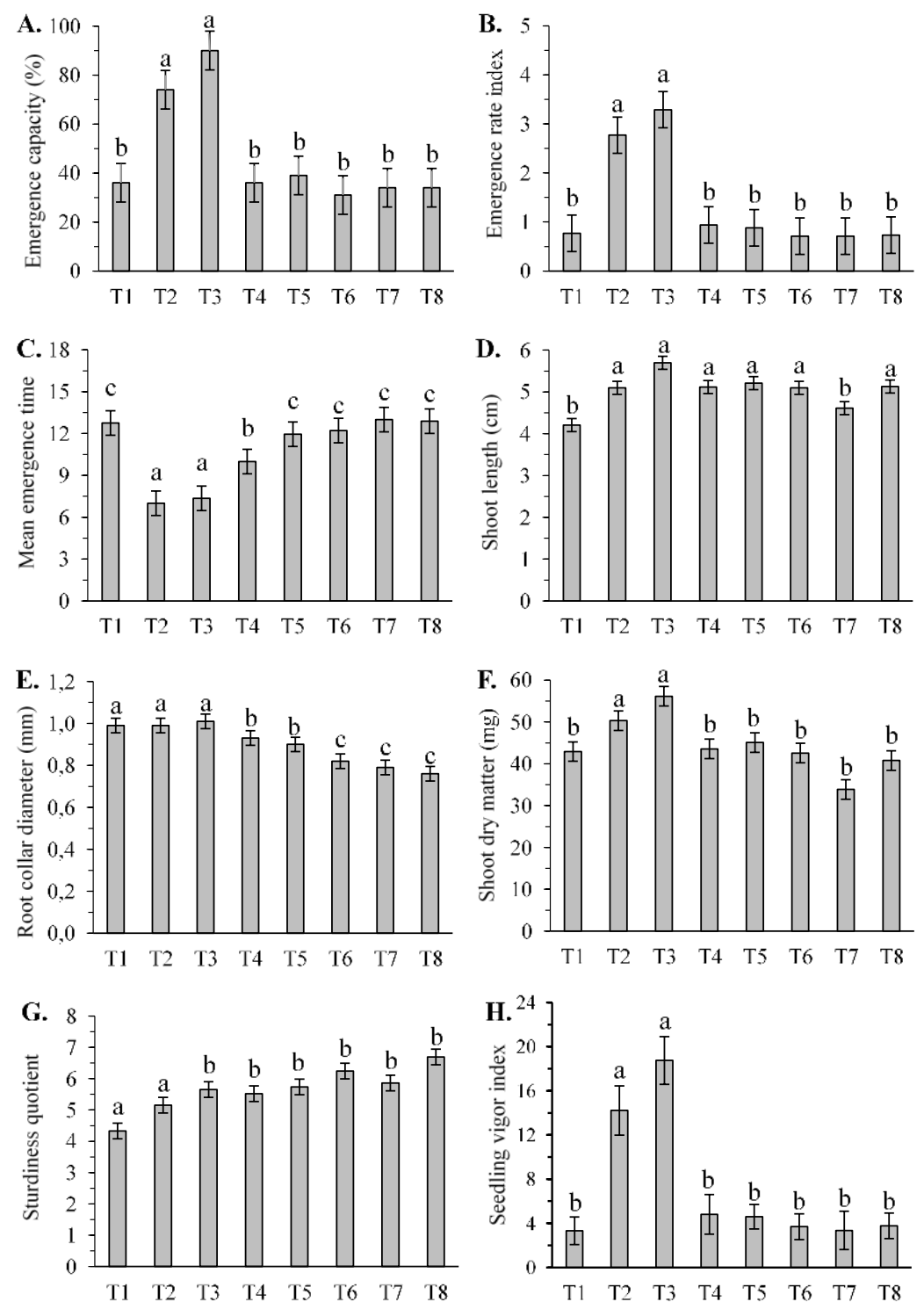

Fig 3. Effects of pre-sowing treatments to break seed dormancy on emergence capacity (A), mean emergence time (B), emergence rate index (C), shoot length (D), root collar diameter (E), shoot dry matter (F), sturdiness quotient $(\mathrm{G})$ and seedling vigor index $(\mathrm{H})$ of canafistula [Peltophorum dubium (Sprengel) Taubert]. Bars followed by the same lower case letters are not significantly different by Scott-Knott test at the 0.05 level of confidence. Data refer to mean values $(n=4) \pm$ standard error. Cassilândia, MS, Brazil, 2016.

Legend: T1 - untreated seeds; T2 - sanding; T3 - soaked in hot water $\left(95^{\circ} \mathrm{C}\right)$ and cooled for 24 hours; T4 - pre-soaking in boiling water $\left(100{ }^{\circ} \mathrm{C}\right)$ for 5 minutes; T5 - exposure to dry heating $\left(40^{\circ} \mathrm{C}\right)$ for 24 hours; T6 - exposure to dry heating $\left(40{ }^{\circ} \mathrm{C}\right)$ for 48 hours; $\mathrm{T} 7$ - exposure to dry heating $\left(40^{\circ} \mathrm{C}\right)$ for 72 hours; and $\mathrm{T} 8$ - exposure to dry heating $\left(40{ }^{\circ} \mathrm{C}\right)$ for 96 hours.

root dry matter and root: shoot dry matter ratio was $0.7782(\mathrm{P}$ $=0.01)($ Table 2$)$. The highest correlation coefficients were observed between the emergence rate index (ERI) and seedling vigor index (SVI) $(\mathrm{r}=0.9944 ; P=0.01)$ and between emergence capacity (EC) and emergence rate index (ERI) $(\mathrm{r}=0.9776 ; P=0.01)$. The high degree of association and significance between these variables were expected, given that the ERI is a test that measures the physiological quality or vigor of seeds. There was a negative and significant correlation between the mean emergence time with the emergence capacity (EC), emergence rate index (ERI), shoot length (SL), root collar diameter (CD), shoot dry matter (SDM) and seedling vigor index (SIV) (Table 2). The root collar diameter correlated negatively and significantly with the sturdiness quotient $(\mathrm{r}=0.7676 ; P=0.01)$ (Table 2). According to Marcos Filho et al. (1984), these significant correlations only show the variations that are similar between two variables, and these findings cannot be analyzed in isolation.

\section{Materials and methods}

\section{Plant material and site characterization}

Seeds of Peltophorum dubium (Spreng.) Taub. ("canafistula") were collected from the 18 years old trees established in savannah areas located at the Mato Grosso do Sul State University (UEMS), in the municipality of Cassilândia, MS, Brazil (1905'20" S, 51 $48^{\prime} 24^{\prime \prime} \mathrm{W}$, and altitude of $470 \mathrm{~m}$ ).

The regional climate according to the Köppen classification is Aw, characterized as tropical climate with hot summers and a tendency towards high rainfall levels, and dry winters, 
with a dry season between May and September. The 30-year mean annual temperature is $24.1^{\circ} \mathrm{C}$ with a July minimum of $16.4{ }^{\circ} \mathrm{C}$ and a January maximum of $28.6^{\circ} \mathrm{C}$, and mean annual rainfall of $1,520 \mathrm{~mm}$. Temperature and rainfall data gathered during the flowering period and fruit formation of P. dubium in the years 2015 and 2016 are shown in Figure 1.

Seeds were previously selected taking into account the seed size and weight. Characterization of the seeds including the weight of a thousand seeds and water content was performed following to the Official Rules for Seed Analysis (Brasil, 2009). The seeds contained $7.75 \pm 0.65 \%$ water content, $700 \pm 50 \mathrm{mg}$ fresh weight, $10.5 \pm 0.5 \mathrm{~mm}$ longitudinal length, and $4.8 \pm 0.2 \mathrm{~mm}$ transverse length.

\section{Experimental design and dormancy breaking treatments}

The experimental was arranged in a completely randomized design, using eight treatments to break seed dormancy of $P$. dubium, with four replications of 25 seeds each. Treatments to break seed dormancy included: T1 - untreated seeds (control); T2 - mechanical scarification (the seed coat was sanded with a sandpaper $\mathrm{N}^{\circ} 80$ at an area opposite to the embryo); T3 - intact seeds soaked in hot water $\left(95^{\circ} \mathrm{C}\right)$, followed by soaking in water at room temperature (24 to 28 $\left.{ }^{\circ} \mathrm{C}\right)$ for 24 hours; T4 - intact seeds soaked in boiling water $\left(100{ }^{\circ} \mathrm{C}\right)$ for 5 minutes, followed by exposure to room temperature $\left(24\right.$ to $\left.28{ }^{\circ} \mathrm{C}\right)$; T5, T6, T7 and T8 - intact seeds exposed to dry heating in an oven at $40{ }^{\circ} \mathrm{C}$ for $24,48,72$ or 96 hours, respectively.

\section{Conditions of germination and seedling growth}

After each treatments, the seeds were immediately placed to germinate in plastic trays $(42 \times 28 \times 6 \mathrm{~cm})$ containing sand. The trays were then maintained under greenhouse conditions for a period of 25 days. The water content of the substrate was maintained at $60 \%$ of the sand field capacity with daily irrigations. Temperature and relative humidity were monitored daily within the greenhouse with the aid of a data logger ITLOG-80 (Instrutemp Measuring Instruments Ltd., São Paulo, SP, Brazil) and data collected during the experiment period (August 16 to September 10, 2016) are shown in Figure 2.

\section{Measurements of seedling emergence and growth}

The emergence capacity (EC), emergence rate index (ERI), mean emergence time (MET), early growth and vigor indexes of $P$. dubium seedlings were measured. The equations $1-3$ and the parameters therein were employed to express the process of seedling emergence.
$\mathrm{EC}(\%)=S_{\mathrm{NG}} / S_{\mathrm{N} 0} \times 100$
[Eq. 1]

where EC is emergence capacity, $S_{\mathrm{NG}}$ is the number of emerged seedlings, and $S_{\mathrm{N} 0}$ is the number of experimental seeds with viability (25 seeds).

$\mathrm{ERI}=\Sigma\left(n_{\mathrm{i}} / t_{\mathrm{i}}\right)$

[Eq. 2]

where ERI is the emergence rate index (seedling day ${ }^{-1}$ ), $n_{\mathrm{i}}$ is the number of emerged seedlings on a given day, and $t_{\mathrm{i}}$ is the time in days from the starting/sowing day (0) (Maguire 1962).

$\operatorname{MET}=\left(\Sigma n_{\mathrm{i}} t_{\mathrm{i}}\right) / \Sigma n_{\mathrm{i}}$

where MET is the mean emergence time (day), $n_{\mathrm{i}}$ is the number of emerged seedlings on a given day, and $t_{\mathrm{i}}$ is the time in days from the starting/sowing day (0) (Labouriau 1983).

The shoot and root length was measured in 10 seedlings randomly obtained after count of the final emergence $\left(25^{\text {th }}\right.$ day) using meter scale. The results were expressed in centimeter $(\mathrm{cm})$. Root collar diameter (in $\mathrm{mm}$ ) was measured by using a digital caliper with accuracy of $0.01 \mathrm{~mm}$. For the determination of dry matter partitioning into roots and shoots, all seedlings obtained at the end of the emergence period $\left(25^{\text {th }}\right.$ day) were separated into roots and shoots, dried in a forced air circulation oven for three days at $65^{\circ} \mathrm{C}$, and then weighed. The results were expressed in milligrams per seedling $(\mathrm{mg}$ seedling ${ }^{-1}$ ). To determine root: shoot ratio (RSR), root dry matter obtained was divided by the shoot dry matter.

After measuring of seedlings, length, diameter and emergence traits, the sturdiness quotient and seedling vigor index, were calculated using the by following equations:

$$
\mathrm{SQ}=S_{\mathrm{L}} / C_{\mathrm{D}} \quad \text { [Eq. 4] }
$$

where $\mathrm{SQ}$ is the sturdiness quotient, $S_{\mathrm{L}}$ is the shoot length in the twenty-fifth day $(\mathrm{cm})$, and $C_{\mathrm{D}}$ is the root collar diameter of seedlings in the twenty-fifth day (mm) (Duryea, 1985).
$\mathrm{SVI}=S_{\mathrm{L}} \times \Sigma\left(n_{\mathrm{i}} / t_{\mathrm{i}}\right)$
[Eq. 5]

where SVI is seedling vigor index, $S_{\mathrm{L}}$ is the shoot length in the twenty-fifth day $(\mathrm{cm}), n_{\mathrm{i}}$ is the number of emerged seedlings on a given day, and $t_{\mathrm{i}}$ is the time in days from the starting/sowing day (0) (Zhang et al., 2007).

\section{Statistical analyses}

The normality of data was previously tested by the Kolmogorov-Smirnov test at the 5\% level and then data were submitted to analysis of variance (ANOVA), and means of dormancy breaking treatments were compared by the ScottKnott test at the 0.05 level of confidence using SISVAR ${ }^{\circledR}$ version 5.3 software for Windows (Statistical Analysis Software, UFLA, Lavras, MG, BRA). For statistical analysis, the data of emergence percentage, emergence rate index and vigor index were previously transformed into $\operatorname{arc} \sin \sqrt{x / 100}$. The Pearson correlation coefficient (Pearson's $r$ ) and respective significance level $(P)$ between the different evaluated traits were calculated using the BIOESTAT $^{\circledR}$ version 5.0 software for Windows (Institute for Sustainable Development Mamirauá, Tefé, AM, BRA).

\section{Conclusion}

Mechanical scarification (sanding) and soaking in hot water $\left(95{ }^{\circ} \mathrm{C}\right.$ ), followed by soaking in water at room temperature ( 24 to $28{ }^{\circ} \mathrm{C}$ ) for 24 hours were efficient to breaking the tegument dormancy and enhance the emergence rate and vigor index of Peltophorum dubium (Fabaceae) seedlings; and, therefore are highly recommended for forest nurseries.

\section{Acknowledgments}

The authors express their gratitude to CAPES (Coordination for the Improvement of Higher Education Personnel) for the granting of PND/Capes scholarships, Mato Grosso do Sul State University for the logistical support.

\section{References}

Brasil. Ministério da Agricultura, Pecuária e Abastecimento (2009) Regras para análise de sementes, Brasília.

Bertolini IC, Debastiani AB, Brun EJ (2015) Caracterização silvicultural da canafístula (Peltophorum dubium (Sprengel) Taubert). Sci Agrar Parana.14(2):67-76.

Bianchetti A, Ramos A (1982) Comparação de tratamentos para superar a dormência de sementes de canafístula Peltophorum dubium (Spreng.) Taubert. Bol Pesqui Florest. 4:91-99. 
Burg VDWJ, Aartse JW, Zwol VRA, Jalink H, Bino RJ (1994) Predicting tomato seedling morphology by X-ray analysis of seeds. J Amer Soc Hort Sci. 119(2):258-263.

Carneiro JGA (1995) Produção e controle de qualidade de mudas florestais. Curitiba: UFPR/FUPEF;

Carvalho PER (2002) Canafístula. Circular Técnica 64, Colombo-PR.

Carvalho PER (2003) Espécies arbóreas brasileiras. Brasília: Embrapa Informação Tecnológica; Colombo: Embrapa Florestas.

Duryea ML (1985) Evaluating seedling quality: principles, procedures, and predictive abilities of major tests. Portland, Oregon, USA: Forest Research Laboratory/Oregon State University.

Guerra MP, Nodari RO, Reis A, Grando JL (1982) Comportamento da canafístula (Peltophorum dubium (Sprengel) Taubert) em viveiro, submetida a diferentes métodos de quebra de dormência e semeadura. Bol Pesqui Florest. 5:1-15.

Kobori NN, Mascarin GM, Cicero SM (2013) Métodos não sulfúricos para superação de dormência de sementes de mucuna-preta (Mucuna aterrima). Inf Abrates 23(1):25-32.

Labouriau LG (1983) A germinação de sementes. Washington: Organização dos Estados Americanos.

Lazarotto M, Mezzomo R, Maciel CG, Bovolini MP, Muniz MFB (2013) Tratamento de sementes de canafístula via calor úmido. Rev Ciênc Agrária 56(3):268-273.
Lorenzi H (2002) Árvores brasileiras: manual de identificação e cultivo de plantas arbóreas nativas do Brasil. $2^{\mathrm{a}}$ ed. Nova Odessa: Editora Plantarum.

Marcos Filho J (2005) Fisiologia de sementes de plantas cultivadas. Piracicaba: FEALQ.

Maguire JD (1962) Speed of germination aid in selection and evaluation for seeding emergence and vigor. Crop Sci. 2(2):176-177.

Marcos Filho J, Pescarin HMC, Komatsu, YH, Demétrio, CGB, Fancelli AL (1984) Testes para avaliação do vigor de sementes de soja e sua relação com a emergência das plântulas em campo. Pesqui agropecu bras. 19(5):605-613.

Oliveira LM, Davide AC, Carvalho MLM (2003) Avaliação de métodos para quebra da dormência e para a desinfestação de sementes de canafístula (Peltophorum dubium (Sprengel) Taubert. Rev Árvore 27(5):597-603.

Salerno AR, Shallenberger TCH, Stuker H (1996) Quebra de dormência em sementes de canafístula. Agropecu Catarin. 9(1):9-11.

Zhang S, Hu J, Zhang Y, Xie Xj, Allen K (2007) Seed priming with brassinolide improves lucerne (Medicago sativa L.) seed germination and seedling growth in relation to physiological changes under salinity stress. Aust J Agric Res. 58(8):811-815. 